\title{
Risk Factors of Stunting in Children Aged 1-5 Years at Wire Primary Health Care, Tuban Regency, East Java
}

\author{
Prastiwi Novia Puspitasari 1), Irwanto'), Annis Catur Adi3) \\ 1)Department of Maternal And Child Health, Faculty Public Health, Airlangga University \\ ${ }^{2)}$ Department of Child Health, Faculty of Medicine, Airlangga University \\ 3)Department of Nutrition, Faculty of Public Health, Airlangga University
}

\section{ABSTRACT}

Background: Stunting is the most common malnutrition condition found in children around the world. Many factors may affect toddler nutritional status and cause stunting in them. They include genetic factors, family socioeconomic level, medical history, and feeding practices. The present study aims to determine factors associated with stunting in children aged 1 to 5 years.

Subjects and Method: This was a cross-sectional study. A sample of 109 mothers with children aged 1 to 5 years was selected by a proportional random sampling. The dependent variable was stunting. The independent variables were genetic factors, family socioeconomic level, medical history, and feeding practices. The data were collected by questionnaire that has been validated for contents. The data were analyzed by a multiple logistic regression.

Results: Short maternal height $(\mathrm{OR}=9.85 ; 95 \%$ $\mathrm{CI}=1.05$ to $92.19 ; \mathrm{p}=0.045$ ), short paternal height $(\mathrm{OR}=1.17 ; 95 \% \mathrm{CI}=49.18 ; \mathrm{p}=0.034)$, low dietary diversity $(\mathrm{OR}=4.94 ; 95 \% \mathrm{CI}=1.06$ to 22.97; $\mathrm{p}=0.042$ ), and low fish consumption $(\mathrm{OR}=3.52 ; 95 \% \mathrm{CI}=1.12$ to $11.08 ; \mathrm{p}=0.031)$ increased the risk of stunting in children.

Conclusion: Short maternal height, short paternal height, low dietary diversity, and low fish consumption increase the risk of stunting in children.

Keywords: stunting, children, socioeconomics

\section{Correspondence:}

Prastiwi Novia Puspitasari. Department of Maternal And Child Health, Faculty of Public Health, Airlangga University. Jl. Mulyorejo, Kampus C Unair, Sukolilo, Surabaya, East Java, Indonesia. Email: prastiwinovia@gmail.com. Mobile: +6285257200109.

Cite this as:

Puspitasari PN, Irwanto, Adi AC (2020). Risk Factors of Stunting in Children Aged 1-5 Years at Wire Primary Health Care, Tuban Regency, East Java. J Matern Child Health. 05(04): 387-395. https://doi.org/10.26911/thejmch.2020.05.04.05.

cc) (i) (2) Journal of Maternal and Child Health is licensed under a Creative Commons Attribution-Non Commercial-Share Alike 4.o International License.

\section{BACKGROUND}

Malnutrition is one of persistent problems in children and toddlers around the world that is extremely difficult to combat. When Millennium Development Goals (MDGs) was set 15 years ago, ending hunger was the first and primary goal. However, it apparently remained an unachieved target in the 2015 MDGs. Nutrition is part of the second goal of Sustainable Development Goals (SDGs) which is Zero Hunger, specifically strives to end hunger and poverty, achieve food security and improved nutrition and promote sustainable agriculture (UNDP, 2020).

Stunting is the most common consequence of malnutrition condition in the world. According to anthropometric measurements in 2010, based on the latest growth standards of WHO, the prevalence of stunting, underweight, and wasting in children aged $<5$ years remains high (40\%, 28\% and 11\%, respectively) (Darapheak., et al 2013). Globally, approximately 165 million children aged $<5$ suffer from stunting, and $90 \%$ of 
these children live in 36 countries, largely in Asia and Africa. Indonesia is ranked fifth among countries with the highest burden of stunted children. More than one third of children aged under five years in Indonesia has below average height. The 2018 Basic Health Research (Riskesdas) recorded national stunting prevalence of $30.8 \%$, meaning, around 7 million of Indonesian, or equals to one out of three, children, suffer from impaired growth (Ministry Of Health, 2018).

Tuban Regency is one of the regions in East Java with a high prevalence of stunted toddlers. In 2014, the number of stunted children in Tuban reached $36.6 \%$, down to $31 \%$ in 2015 and 28\% in 2016 (PSG Jatim, 2016). Although a downward trend of stunted toddlers was observed in the region each year, the prevalence of stunted toddlers in the last three years in the region is still above the prevalence of East Java Province, which means this remains a problem for the Tuban Regency Government(Ministry Of Health, 2018).

Tuban Regency is a coastal area north of Java, so it has animal food resources from the sea, especially abundant fish. A study by Rachim and Pratiwi(2017)shows that a significant relationship is found in the consumption of fish species on stunting. Fish consumption in Tuban Regency is still relatively low. Where Tuban fish consumption per capita is only 45,824 tons per year. Lower with the need to eat fish per capita which reaches 52,564 tons per year (East Java Fisheries and Maritime Service, 2014). In addition, in Tuban there is a traditional food named ampo. The basic ingredients of this food are pure clay, without any mixture. Ampo is usually consumed as snack. This traditional food is mostly consumed by pregnant women who crave because it has a distinctive odor. Consuming these snacks can also pose risks and worries because so far there has been no research on the benefits of ampo for health.
Stunting has both short-term and longterm impacts on individuals and society. The short-term impacts of stunting are related to increased risk of morbidity and mortality due to infectious diseases, especially pneumonia, diarrhea and immunodeficiency. Stunting is one of the main risk factors along with inadequate cognitive stimulation, iodine deficiency and iron deficiency which results in failure to achieve proper child development (Walkeret al., 2011). Stunting affects cognitive function, memory and locomotor capabilities in the brain regions (Ranade et al., 2008). Many factors, both direct and indirect, may influence toddler nutritional status and contribute to stunting condition. This study aims to analyze the impact of genetic factors, sosioeconomic factors, medical history, and feeding practice on stunting incidence in children aged 1-5 years at Wire Primary Health Care Tuban Regency.

\section{SUBJECTS AND METHOD}

\section{Study Design}

This study was analytic observational in design with cross-sectional approach.

\section{Population and Sample}

The sample of the study was109 mothers with children at Wire Primary Health Care, Tuban Regency aged 1 to 5 years.

\section{Study Variables}

The dependent variables were stunting.The independent variable wasgenetic factors (maternal height and paternal height), family socioeconomic level (maternal education, maternal occupation, family members, family income), medical history (birth weight, immunization history) and feeding practices (breastfeeding history, complementary feeding history, breastfeeding length, dietary diversity, feeding frequency, fish consumption, ampo consumption)

4. Operational Definition of Variables Maternal height was defined as the actual height of mother at this time. 
Paternal height was defined as the actual height of father at this time.

Maternal education was defined as the highest formal education levels attained by mother.

Family size was defined as the number of family members and people who live together in one house and depend on the same source of livelihood and consume food provided with family members.

Family income was defined as the average income a family gets per month

Birth weight was defined as the actual weight of the infants at birth.

Immunization history was defined as types of immunizations that have been obtained by children including complete basic immunization (BCG, diphteria, Hepatitis B, Polio, and Measles).

History of breastfeeding was defined as children received breast milk without any supplementary feeding at the age of o-6 months

History of complementary feeding was defined as provision of supplementary food to children other than breast milk from the age of 6 months.

Duration of breastfeeding was defined as the last age for breastfeeding in children.

Dietary diversity was defined as diversity of food groups consumed in one day.

Feeding frequency was defined as frequency of eating whole foods for toddlers given in a day.

Fish consumption was defined as the number of fish (gram) consumed by children 1-5 years per day in a week.

Ampo consumption was defined as never or not eating snacks ampo from birth to current age.

\section{Study Instruments}

The researcher conducted direct interviews with mothers or families with a child aged 1 to 5 years while they were filling in the questionnaire. The height measurement of todd- lers was performed by the researcher using a microtoise for children aged $>24$ months and a baby length board for children aged 24 months. If children aged $<24$ months were measured standing up, $0.7 \mathrm{~cm}$ were added to the measurement results. If children aged $>24$ months were measured lying down, 0.7 $\mathrm{cm}$ were deducted from the measurement results. The results were stated with $\mathrm{z}$ standard deviation (Z-score) in WHO Height/Age chart. Likewise, the height of parentswas measured using a microtoise.

\section{Data Analysis}

The data were analyzed using a simple logistic regression with a significance level of $5 \%$ to determine the impact of those factors on stunting incidence in children aged 1 to 5 years.

\section{Research Ethic}

Ethical clearance was obtained from the Ethical Review Board of Airlangga University.

\section{RESULTS}

\section{Sample Characteristics}

The total sample of respondents in this study were 109 children. $61.5 \%$ of children aged 1 to 5 years were in the normal category, while the rest (38.5\%) were in the stunting category (Table 1). The characteristics of each factor were presented in Table 1.

Socioeconomic characteristics showed that the majority of the mothers (57.8\%) had lower education and as many as $77.1 \%$ mothers were a homemaker. In terms of family size, the majority of the families (63.3\%) were the realization of NKKBS (Norma Keluarga Kecil Bahagia dan Sejahtera/Prosperous and Happy Small Family) ( $\leq 4$ persons). The distribution of month family income was classified according to the minimum wage of Tuban Regency. More than half of the families (51.4\%) had income below the minimum wage.Regarding the immunization history, only 2 infants whose basic im- 
Puspitasari et al./ Risk factors of stunting in children aged 1-5 years

munization history was incomplete. The basic vaccine missing was BCG vaccine.

Table 1. Distribution of stunting incidence in children aged 1 to 5 years

\begin{tabular}{|c|c|c|c|}
\hline Characteristics & & $\mathbf{n}$ & $\%$ \\
\hline \multirow[t]{2}{*}{ Child nutritional status } & Normal & 67 & 61.5 \\
\hline & Stunting & 42 & 38.5 \\
\hline \multirow[t]{3}{*}{ Mother height } & $<155 \mathrm{~cm}$ & 44 & 40.4 \\
\hline & $155^{-160} \mathrm{~cm}$ & 52 & $47 \cdot 7$ \\
\hline & $>160 \mathrm{~cm}$ & 13 & 11.9 \\
\hline \multirow[t]{3}{*}{ Father height } & $<155 \mathrm{~cm}$ & 17 & 15.6 \\
\hline & $155^{-160} \mathrm{~cm}$ & 47 & 43.1 \\
\hline & $>160 \mathrm{~cm}$ & 45 & 41.3 \\
\hline \multirow[t]{3}{*}{ Mother's Education } & Low (<Senior high school) & 63 & 57.8 \\
\hline & Middle ( $\geq$ Senior high school) & 26 & 23.9 \\
\hline & High (College or equivalent) & 20 & 18.3 \\
\hline \multirow[t]{7}{*}{ Mother's Job } & Homemaker & 84 & 77.1 \\
\hline & Farmer/Fisherperson & 4 & 3.7 \\
\hline & Labour/Handyperson & 3 & 2.8 \\
\hline & Trader & 6 & $5 \cdot 5$ \\
\hline & Civil servants & 2 & 1.8 \\
\hline & Private employee & 7 & 6.4 \\
\hline & Other & 3 & 2.8 \\
\hline \multirow[t]{2}{*}{ Family Size } & In accordance with NKKBS ( $\leq 4$ persons) & 69 & 63.3 \\
\hline & Not in accordance with NKKBS ( $>4$ persons) & 40 & 36.7 \\
\hline \multirow[t]{2}{*}{ Family Income } & Low income $(<$ minimum regional wage $)$ & 56 & 51.4 \\
\hline & High income ( $\geq$ minimum regional wage) & 53 & 48.6 \\
\hline \multirow[t]{2}{*}{ Birth Weight } & $<2500$ grams & 13 & 11.9 \\
\hline & $\geq 2500$ grams & 96 & 88.1 \\
\hline \multirow[t]{2}{*}{ Immunization History } & Complete basic vaccines & 107 & 98.2 \\
\hline & Incomplete basic vaccines & 2 & 1.8 \\
\hline Exclusive breastfeeding & Exclusive breastfeeding & 72 & 66.1 \\
\hline \multirow[t]{2}{*}{ history } & Predominant breastfeeding & 3 & 2.8 \\
\hline & Partial breastfeeding & 34 & 31.2 \\
\hline \multirow{2}{*}{ Complementary feeding } & Adequate & 98 & 89.9 \\
\hline & Inadequate & 11 & 10.1 \\
\hline \multirow[t]{2}{*}{ Length of breastfeeding } & $<2$ years & 42 & 38.5 \\
\hline & $\geq 2$ years & 67 & 61.5 \\
\hline \multirow[t]{2}{*}{ Dietary diversity } & Non-nutritious (Skor $\leq 5$ ) & 17 & 15.6 \\
\hline & Nutritious (Skor $\geq 6$ ) & 92 & 84.4 \\
\hline \multirow[t]{2}{*}{ Feeding frequency } & $\geq 3$ times per day & 73 & 67 \\
\hline & $<3$ times per day & 36 & 33 \\
\hline \multirow[t]{2}{*}{ Fish consumption } & Inadequate ( $<19$ grams per day) & 34 & 31.2 \\
\hline & Adequate ( $\geq 19$ grams per day) & 75 & 68.8 \\
\hline \multirow[t]{2}{*}{ Ampo consumption } & Yes & 2 & 1.8 \\
\hline & Never & 107 & 98.2 \\
\hline
\end{tabular}

Characteristics of feeding practices showed that the majority of the mothers (66.1\%) gave their children exclusive breastfeeding. In terms of complementary feeding, gave their children exclusive breastfeeding. In terms of complementary foods, the majority of the mothers (89.9\%) had adequately served complementary foods. In general, mothers provided complementary foods in the form of instant milk porridge or homemade porridge mixed with vegetable soup and side dishes. The majority of the infants (61.5\%) were breastfed until the age of $\geq 2$ years. In terms of fish consumption, $68.8 \%$ 
infants were already given fish in adequate portion which was $\geq 19$ grams/day. Furthermore, only 2 infants had eaten ampo in tiny portion. Ampo snack was given when the children were left with their grandmothers.

\section{The result of multivariate analysis}

Table 2 showed the results of a multiple logistic regression. Table 3 showed that short maternal height $(\mathrm{OR}=9.85 ; 95 \% \mathrm{CI}=1.05$ to 92.19; $\mathrm{p}=0.045)$, short paternal height $(\mathrm{OR}=$ 1.17; 95\% $\mathrm{CI}=49.18 ; \mathrm{p}=0.034)$, low dietary diversity $(\mathrm{OR}=4.94 ; 95 \% \mathrm{CI}=1.06$ to 22.97 ; $\mathrm{p}=0.042)$, and low fish consumption (OR= 3.52 ; $95 \% \mathrm{CI}=1.12$ to 11.08 ; $\mathrm{p}=0.031)$ increased the risk of stunting in children.

Table 2. The results of a multiple logistic regression on the determinants of stunting

\begin{tabular}{lcccc}
\hline \multirow{2}{*}{ Independent Variables } & \multirow{2}{*}{ OR } & \multicolumn{2}{c}{ 95\% CI } & \multirow{2}{*}{ p } \\
\cline { 3 - 4 } & & Lower limit & Upper limit & \\
\hline Maternal height (short) & 9.85 & 1.05 & 92.19 & 0.045 \\
Paternal height (short) & 7.58 & 1.17 & 49.18 & 0.034 \\
Dietary diversity (low) & 4.94 & 1.06 & 22.97 & 0.042 \\
Fish consumption (low) & 3.52 & 1.12 & 11.08 & 0.031 \\
Constant & 0.07 & & & 0.014 \\
$\mathrm{~N}=109$ & & & & \\
$\mathrm{p}=0.050$ & & & & \\
\hline
\end{tabular}

\section{DISCUSSION}

Maternal height is an intergenerational indicator that links nutrition and maternal and child health. The results showed that the height of the fathers and the mothers contributed to stunting incidence in children aged 1 to 5 years. This was in line with the study by Sinha et al. (2017) showing that the lengthfor-age Z-scores (LAZ) of babies from mothers with short stature were significantly lower than babies from mothers with a height of $\geq 150 \mathrm{~cm}$. in women with short stature, physical mechanisms such as the development of the anatomical system of pregnancy and the metabolic mechanisms were nonoptimal, for example, low maternal glucose levels and reduced protein and energy storage. Those things contributed to impaired intrauterine development and delayed linear growth of infants (Sinha et al., 2017).

The results were also in line with the study by Khatun et al. (2019) in Bangladesh. It pointed out that maternal short stature was an indicator of cumulative nutritional deficiencies during the growth period. Poor nutritional status of women during pregnancy adversely affected the growth of the placenta, which caused inadequate transfer of nutrients to the fetus. Undernutrition in the uterus caused epigenetic modification (i.e., DNA methylation) to alter fetal programming resulting in abnormal fetal growth, and ultimately, low birthweight babies (LBW). LBW babies born with nutritional deficiency and immature immune system were more susceptible to infections, while infections increased the risk of acute malnutrition due to mucosal damage, impaired absorption of essential nutrients, and weight loss (Khatun et al., 2019).

Our study proves that family socioeconomic factors do not have a significant effect on stunting in children. Research on socioeconomic factors for the incidence of stunting in children remains controversial. Research in Kenya shows that mother's education level does not affect the nutritional status of children. Based on the results of the study the majority (84.6\%) of mothers / care givers had reached primary education level, 5.0\% had no formal education, $5.0 \%$ had secondary education, and only $4.4 \%$ had completed secondary education. While a significant influence was found between two factors, 
namely marital status and caregiver occupation (M'Kaibi et al., 2017).Studying Mexico show that household per capita income does not include factors that influence the nutritional status of children under five, this is related to the ability of families in coping with difficult environments and further microeconomic analysis studies are needed to determine this relationship (Reyes et al., 2014).

The results of logistic regression analysis in the present study showed that birth weight and immunization history did not influence stunting incidence in children aged 1 to 5 years. Teoriticaly, the impact from low birth weight will pass onto the next generation. A study demonstrated that children with LBW have a risk of 5.87 times to have stunting. Birth weight is generally strongly associated with fetal, neonatal and post-neonatal mortality, infant and child morbidity and long-term growth and development. The impact of babies who have low birth weight will continue from generation to generation, children with LBW will have a lack of anthropometric size on its development (Koetaan et al., 2018). Another study in India showed that no significant relationship was found between the completeness of immunization and stunting incidence (Ahsan et al., 2017).

The results showed that there was no correlation between breastfeeding and stunting incidence in children aged 1 to 5 years. Several studies on the relationship of breastfeeding with nutritional status in children have had mixed results. A study in Rwanda showed a significant relationship between stunting and children who are breastfed. Children with breast milk have 0.02 times lower risk of having stunting than children who do not get breast milk (Habimana and Biracyaza, 2016). Another study by Khan and Islam (2017) shows different results based on the results of the study, a history of exclusive breastfeeding is not associated with stunting, wasting and underweight. This is quite consistent in previous studies conducted in developing countries.

Our study showed that Dietary Diversity had an effect on stunting incidence in children aged 1 to 5 years ( $p<0.0001)$. The probability of stunting in families with low dietary diversity score was 0.142 higher than families with greater dietary diversity score. This was in line with a study in Kenya (2017) showing that dietary diversity in families with stunted children differed significantly to families without stunted children (M'Kaibi et al., 2017). Probability of stunting, wasting and underweight was found to decrease as the number of food groups consumed increased. Children who did not receiving Minimum Dietary Diversity (MDD) were more likely to be stunted and underweight compared to children who did. Variety of consumption, as a marker of adequacy of micronutrients, could increase nutrient density of complementary foods, which promoted optimal growth and development of children. Receiving monotonous and inadequate foods could lead to malnutrition, and make children vulnerable to opportunistic infections and severe illness.

Based on the results, $73.5 \%$ of children lacking in fish consumption and $22.7 \%$ of children receiving adequate fish intake suffered from stunting. The results of logistic regression analysis showed that fish consumption had an effect on stunting incidence of children aged 1to 5 years ( $p<0.0001)$. The probability of stunting was 0.106 higher in children lacking fish consumption compared to those who ate enough fish. A study in Zambia showed that the amount of fish consumed by children was correlated with stunting in children aged 6-23 months and 24-59 months. It showed the length/heightfor-age Z-scores (HAZ) related to fish consumption. The majority of children that consumed fish were in normal HAZ score 
range. Logictic regression results show the amount of fish consumed by the children showed better nutritional results (normal HAZ). Small fish species found in developing countries have been shown to contain micronutrient levels of vitamin $\mathrm{A}$, iron and zinc which were very important for children's growth and development. Fishes were also rich in vitamin B12, which could only be found in animal foods and was also essential for various functions such as growth function, brain function, and maintenance of the nervous system. Small fishes were an important source of calcium, a particularly vital element for child diet, that were abundantly available biologically (Marinda et al., 2018).

The results showed that ampo snack had no contribution to stunting incidence in children aged 1 to 5 years. In the present study, only two respondents whose children had eaten ampo, one of which suffered from stunting. The consumption of this snack also evoked risks and worries since there was no scientific proof of the benefits of ampo for health, especially for child nutrition. Nowadays, ampo is no longer consumed by the general public. Most people who still consume ampo were the elderly. The mothers in this study said that it was the grandmothers who gave to their children, but only in small amount since the children refused to eat it.

The highest OR value is owned by the mother's height variable so with this result the most cause of stunting is the mother's height. Study conducted in Palestine in 2017 prove that maternal height has a significant influence on stunting. Children born to mothers whose height is 1.55 to $1.60 \mathrm{~m}$ or $<1.55 \mathrm{~m}$ are more likely to experience stunting than children born to mothers whose height is $>\mathbf{1 . 6 0} \mathrm{m}$. Early life factors including poor maternal health and nutrition before, during and after pregnancy are associated with increased failure of child growth. The long-term impact of poor mater- nal health status, and inadequate nutrient supply for the fetus can cause poor growth and low birth weight, which can affect the health and survival of children (Kishawi et al., 2017).

Our study concludes that genetic factors, such as mother height and father height, dietary diversity and fish consumption influence stunting incidence in children aged 1 to 5 years at Wire Primary Health Care ,Tuban Regency. In order to combat stunting, there is a need for a strategy focusing on guiding mothers who have children with stunting with the aim of improving the quality of feeding practices, especially related to dietary diversity and fish consumption. Furthermore, interventions that are able to overcome the factors are needed such as community-based education or a dedicated program to expand the knowledge and skills of housewives regarding the provision of quality nutrition for children.

\section{AUTHOR CONTRIBUTION}

Prastiwi Novia Puspitasari was involved in conceptualising the study, reviewing the literature, designing the protocol, developing the questionnaire, data collection, statistical analysis, and preparing the manuscript. Irwanto and Annis Catur Adi was involved in conceptualising the study, developing the questionnaire, and critically reviewed the manuscript. All authors read and approved the final manuscript

\section{CONFLICT OF INTEREST}

The authors declare that they have no conflict of interests.

\section{FUNDING AND SPONSORSHIP}

None.

ACKNOWLEDGEMENT

We would like to thank the respondentswho gave us their valuable time for data collection. First and foremost, we acknowledge the 
Puspitasari et al./ Risk factors of stunting in children aged 1-5 years

community members who participated in this study. We also gratefull to Wire Primary Health Care for their support and co-peration

\section{REFERENCE}

Ahsan S, Mansoori N, Mohiuddin S, Mubeen, S, Saleem R, Irfanullah M (2017). Frequency and determinants of malnutrition in children aged between 6 to 59 months in district Tharparkar, a rural area of Sindh. J Pak Med Assoc, 67(9): 1369-1373.

Darapheak C, Takano T, Kizuki M, Nakamura K, Seino K (2013). Consumption of animal source foods and dietary diversity reduce stunting in children in Cambodia. Int Arch Med, 6: 29. https://dx.doi.org/10.1186\%2F1755-7682-629.

Habimana S, Biracyaza E (2016). Risk factors of stunting among children under 5 years of age in the Eastern and Western Provinces of Rwanda: Analysis of Rwanda demographic and health survey 2014/2015. Pediatrics Health Med Ther, 10: 115-130. https://dx.doi.org/10.2147\%2FPHMT.S222198.

Khan K, Islam M (2017). Effect of exclusive breastfeeding on selected adverse health and nutritional outcomes: a nationally representative study. BMC Public Health, 17(1): 889. https://doi.org/10.1186/s12889-017-4913-4

Khatun W, Rasheed S, Alam A, M Huda T, Dibley M (2019). Assessing the Intergenerational Linkage between Short Maternal Stature and Under-Five Stunting and Wasting in Bangladesh. BMJ Global Health. 3: eooo881. http://dx.doi.org/10.1136/bmjgh-2018-000881.

Kishawi R, Soo K, Abed Y, Wan Muda A (2017). Prevalence and associated factor sinfluencing stunting in children aged 2-5 years in the Gaza Strip-Palestine: a cross-sectional study. BMC
Pediatrics, 17: 210. https://doi.org/10.1186/s12887-017-0957-y.

Koetaan D, Smith A, Liebenberg A, Brits M, Halkas C, van Lill M, Joubert G (2018). The prevalence of underweight in children aged 5 years and younger attending primary health care clinics in the Mangaung area, Free State. Afr J Prim Health Care Fam Med, 10(1): 1476. https://dx.doi.org/10.4102\%2Fphcfm.v10i1.1476.

Marinda P, Genschick S, Christoper KW, Kiwanuka-Lubinda R, Thilsted S (2018). Dietary diversity determinants and contribution of fish to maternal and underfive nutritional status in Zambia. PLoS ONE, 13(9): e0204009. https://doi.org/10.1371/journal.pone.0204009.

Ministry of Health of Indonesia (2018). Buku Saku Hasil PSG 2016. Retrieved from http://www.kesmas.kemkes.go.id/assets/upload/dir_519d41d8cd98foo/files/Buku-Saku-Hasil-PSG-2016_842.pdf.

Ministry of Health of Indonesia (2020). Hasil riskesdas 2018. Retrieved from www.depkes.go.id/resources/download/general/Hasil\%2oRiskesdas\%202018.pdf.

M'Kaibi F, Steyn N, Ochola S, Plessis L (2017). The relationship between agricultural biodiversity, dietary diversity, household food security, and stunting of children in rural Kenya. Food Science and Nutrition, 5(2):234-254. https://doi.org/10.1002/fsn3.387.

Rachim ANF, Pratiwi R (2017). Hubungan konsumsi ikan terhadap kejadian stunting pada anak usia 2-5 tahun. Jurnal Kedokteran Diponegoro, 6(1): 36-45.

Ranade S, Rose A, Rao M, Galleg J, Gressens $P$, Mani S (2008). Different types of nutritional deficiencies affect different domains of spatial memory function 
Puspitasari et al./ Risk factors of stunting in children aged 1-5 years

checked in a radial arm maze. Neuroscience, 152(4): 859-866. https://doi.org/10.1016/j.neuroscience.2008.01.002.

Reyes H, Cuevas R, Sandoval A, Castillo R, Santos JI, Doubova SV, Gutierrez, G (2014). The family as a determinant of stunting in children living in conditions of extreme poverty: a case-control study. BMC Public Health, 4(1):57. Doi: 10.1186/1471-2458-4-57.

UNDP (2020). Sustainable development goals. Retrieved From undp.org: https:- //www.undp.org/content/undp/en/home/sustainable-development-goals.html

Walker S, Wachs T, Grantham-McGregor S, Black M, Nelson C, Huffman S (2011). Inequality in early childhood: Risk and protective factors for early child development. Lancet, 378(9799): 13251338. https://doi.org/10.1016/So1406736(11)60555-2.

Wibisono D (2008). Riset Bisnis. Bandung: Ganesha Exact. 